This is an electronic reprint of the original article. This reprint may differ from the original in pagination and typographic detail.

Author(s): Henderson, Alice; Curnick, Lesley; Frost, Dan; Kautzsch, Alexander; Kirkova-Naskova, Anastazija; Levey, David; Tergujeff, Elina; Waniek-Klimczak, Ewa

Title: $\quad$ The English Pronunciation Teaching in Europe Survey : Factors Inside and Outside the Classroom

Year: $\quad 2015$

Version:

Please cite the original version:

Henderson, A., Curnick, L., Frost, D., Kautzsch, A., Kirkova-Naskova, A., Levey, D., Tergujeff, E., \& Waniek-Klimczak, E. (2015). The English Pronunciation Teaching in Europe Survey : Factors Inside and Outside the Classroom. In J. A. Mompean, \& J. Fouz-González (Eds.), Investigating English Pronunciation : Current Trends and Directions (pp. 260-291). Palgrave Macmillan.

https://doi.org/10.1057/9781137509437_12

All material supplied via JYX is protected by copyright and other intellectual property rights, and duplication or sale of all or part of any of the repository collections is not permitted, except that material may be duplicated by you for your research use or educational purposes in electronic or print form. You must obtain permission for any other use. Electronic or print copies may not be offered, whether for sale or otherwise to anyone who is not an authorised user. 
*This article will appear in early 2015 in Investigating English Pronunciation: Current Trends and Directions, published by Palgrave-Macmillan and edited by Jose A. Mompean \& Jonas Fouz. Please do not quote this version, as changes may still be made. If you have questions, please contact Alice Henderson: alice.henderson@univ-savoie.fr

\title{
THE ENGLISH PRONUNCIATION TEACHING IN EUROPE SURVEY: FACTORS INSIDE AND OUTSIDE THE CLASSROOM ${ }^{1}$
}

Alice Henderson ${ }^{1}$, Lesley Curnick ${ }^{2}$, Dan Frost ${ }^{3}$, Alexander Kautzsch ${ }^{4}$, Anastazija Kirkova-Naskova ${ }^{5}$, David Levey $^{6}$, Elina Tergujeff ${ }^{7}$, Ewa Waniek-Klimczak ${ }^{8}$

\footnotetext{
${ }^{1}$ University of Savoie, France

${ }^{2}$ University of Lausanne, Switzerland

${ }^{3}$ University of Savoie, France

${ }^{4}$ University of Regensburg, Germany

${ }^{5}$ University of Skopje, Macedonia

${ }^{6}$ University of Cadiz, Spain

${ }^{7}$ University of Jyväskylä, Finland

${ }^{8}$ University of Lodz, Poland
}

\begin{abstract}
This paper presents a subset of findings from a European-wide, on-line survey of English pronunciation teaching practices (EPTiES). Quantitative and qualitative data from seven countries (Finland, France, Germany, Macedonia, Poland, Spain and Switzerland) are presented, focusing on teachers' comments about the training they received to teach English pronunciation, about what they do inside the classroom and about what happens outside the classroom in terms of students' exposure to English. The results of EPTiES and of follow-up interviews reveal interesting phenomena across Europe. Most of the teacher-respondents were non-native speakers of English and felt they had little or no training in how to teach pronunciation, which raises the question of how teachers are coping with this key aspect of language teaching. Differences between countries are explored, especially via replies to open-ended questions and relevant contextual factors (e.g. language policy) allowing a more nuanced picture to emerge for each country. Suggestions are made for improving teacher training and for further research.
\end{abstract}

Key words: English, pronunciation, Europe, survey, teaching.

\section{Introduction}

In the past two decades, a number of studies have looked at how English pronunciation is taught, focusing on teaching practices, materials, training and attitudes to native speaker models from both the teachers' and the learners' perspective. Most of these studies have been conducted in English-speaking countries such as the USA (Murphy 1997), Great Britain (Bradford \& Kenworthy 1991, Burgess and Spencer 2000), Canada (Breitkreutz et al. 2001, Foote et al. 2011) and Australia (Couper 2011, Macdonald 2002). In Europe, pronunciation teaching has been studied in Spain (Walker 1999) and, more recently, in Ireland (Murphy 2011) and Finland (Tergujeff 2012, 2013a, 2013b). Work has also looked at attitudes towards native speaker models and the degree of success in reaching the model, for example, in Poland (Nowacka 2010, Waniek-Klimczak and Klimczak 2005, Waniek-Klimczak 2002), Serbia (Paunović 2009) and Bulgaria (Dimitrova and Chernogorova 2012). In Finland, Lintunen (2004) and Tergujeff et al. (2011) focussed on learners, not teachers, but both studies included a survey section exploring methods in English pronunciation teaching.

These studies examined important aspects of the issue but, to the best of our knowledge, no study has extensively investigated and compared how English pronunciation is taught in different European countries. The English Pronunciation Teaching in Europe Survey (EPTiES) seeks to fill this gap. It is a collaborative

\footnotetext{
${ }^{1}$ Alice Henderson assumes responsibility for the present paper and the other authors are listed alphabetically. They all contributed to the EPTiES project and to this article (survey design, data collection, data analysis, writing and editing).
} 
project in which teachers and researchers in ten European countries compiled data in order to facilitate comparisons of European practices (Henderson et al. 2012). This paper looks at what teachers from seven countries said about three interrelated aspects: the training they received to teach English pronunciation; what happens inside the classroom (teaching methods and materials, evaluation of pronunciation); and what happens outside the classroom (type and frequency of learners' exposure to English in society at large). Analysis of the results includes reference to other research and national language policy actions.

\section{The Survey and Participants}

The survey's 57 questions (multiple-choice, Likert-scale and open-ended questions) were devised by the authors and other participants ${ }^{2}$ over a one year period, via e-mail, meetings at conferences and phone conversations ${ }^{3}$. The full list of questions appears in the Appendix. The items were chosen in relation to each individual's interests or specific lines of inquiry based on our experience as teachers and researchers, not within the framework of a specific theory or from a desire to use an existing questionnaire with new populations ${ }^{4}$. Questions were grouped into nine categories in the on-line survey, which was designed and administered using the open-source application LimeSurvey. Data were collected on-line from February 2010 until September 2011. Responses were obtained from 843 EFL/ESL teachers from 31 European countries. Attempts were made to contact teachers at all levels of the private and public sectors. To do this, we used several means, including personal contacts and mailing lists of professional bodies such as teachers' associations (e.g. SUKOL in Finland, TESOL-France, ELTAM in Macedonia, ETAS in Switzerland). We also contacted educational institutions and administrative structures in Finland, France and Germany. Invitations were distributed internationally via the Linguist List and "promotional" bookmarks were handed out at various conferences over a two-year period.

The present paper is based on the 640 respondents from the seven countries for which at least twelve teachers completed the survey in its entirety: Finland, France, Germany, Macedonia, Poland, Spain and Switzerland (Table 1).

\begin{tabular}{|c|c|}
\hline Category & $\begin{array}{c}\mathbf{N}^{\circ} \text { of respondents per country } \\
\text { (including incomplete replies) }\end{array}$ \\
\hline Finland (FI) & 103 \\
\hline France (FR) & 65 \\
\hline Germany (DE) & 362 \\
\hline Macedonia (MK) & 36 \\
\hline Poland (PL) & 20 \\
\hline Spain (ES) & 31 \\
\hline Switzerland (CH) & 23 \\
\hline Total & $\mathbf{6 4 0}$ \\
\hline
\end{tabular}

Table 1. Participants per country and total $n^{\circ}$ of respondents.

As the survey was long, some participants did not complete every section. For example, many people did not answer open-ended questions or questions about age or professional qualifications. Therefore, in the following tables of this paper the number of respondents for a given question is always indicated and may

\footnotetext{
${ }^{2}$ Deirdre Murphy (Trinity College, Dublin) and Una Cunningham (University of Canterbury, Christchurch) were of considerable help from the very start but had too few respondents for the current analysis.

${ }^{3}$ Some of the advantages and drawbacks of such collaborative research are addressed in Henderson (2013).

4 Special mention must be made of the extensive work using questionnaires done by Polish colleagues, for example Marta Nowacka, Włodzimierz Sobkowiak and Katarzyna Janicka, Małgorzata Kul \& Jarosław Weckwerth. We were inspired by their work, although we did not use their exact questions.
} 
differ from the initial figures in Table 1. In the analysis, all responses were considered for the parts of the questionnaire that were filled in. Averages were calculated for the quantitative data (multiple-choice and Likert-scale questions). The open-ended questions were analysed qualitatively by coding the answers for recurrent themes (Dörnyei and Taguchi 2009). Follow-up interviews were also done with ten of the respondents in France.

Most of the respondents were female but there were some major differences between countries: $95 \%$ in Finland, 92\% in Macedonia, 83\% in Switzerland, 75\% in France and Poland, and 72\% in Germany but only $52 \%$ in Spain. Most respondents were non-native speakers (90\%), rising to $96 \%$ in Germany, $99 \%$ in Finland and $100 \%$ in Macedonia and Poland. In France and Spain three-quarters of respondents were nonnative speakers, whereas in Switzerland they were predominantly native English speakers (83\%).

Both younger and older teachers participated, the average age being 43 years and mean teaching experience 16 years. The lowest average age and years of experience was for the Polish respondents: 17 of the twenty participants were aged between 22 and 26 and had 2 to 3 years' teaching experience. This is significantly lower than the overall survey average of 16 years' teaching experience. The range of age and experience was slightly higher for respondents in Macedonia: average age 29 (from 28 to 50 years) and 8 years' teaching experience (from 3 to 34 years). On average the Finnish respondents were aged 45 years and had 16 years' teaching experience. The German figures are almost exactly the same as those in Finland. Even though France and Switzerland have the same average age (46), the former averaged 21 years' teaching experience as against 15 years in Switzerland. In France - where it can be difficult to qualify as a public-sector teacher or to come into the profession after another career - respondents tend to be career teachers from the outset, whereas in Switzerland, English teaching is perhaps not the participants' first career. Finally, almost half (45\%) of Spanish respondents were over the age of 45 with more than 15 years' experience.

Two descriptive questions were asked about learners: "What is the average age range of your learners? Please choose only one of the following:" and "Please indicate at which level you teach." Options for the first question were overlapping age brackets (under 3 years old, 3 to 7 years old, 6 to 10 years, 9 to 12 years, 11 to 15 years, 14 to 18 years, 17 to 22 years, etc.). The choices available in the second question were specific to each country, because European countries do not split learners neatly into the same age brackets. For example, in Germany 10-18 year olds can be taught in three different types of school, thus $41 \%$ of the participants taught at Gymnasium (learners aged 10 to 18), 21\% taught at Realschule (age 10 to 16), and $14 \%$ taught at Hauptschule (age 10 to 15). Each response was only counted once but conflicts did arise. In such cases, priority was given to the "named level", so that if a participant ticked Realschule for the "level" question but chose the age bracket 9 to 12 years old for the "age" question, in Table 2 their choice was categorised in the combined " 11 to 18 years old" category. The results are presented in three combined, overlapping groups (Table 2), beginning with the youngest age at which children start public schooling (age $\left.6^{5}\right)$ :

\begin{tabular}{|c|c|c|c|}
\hline & 6-12 years old & $\mathbf{1 1}-\mathbf{1 8}$ years old & $\geq \mathbf{1 7}$ years old \\
\hline Finland $(\mathrm{n}=77)$ & $31 \%$ & $53 \%$ & $16 \%$ \\
\hline France $(\mathrm{n}=52)$ & $0 \%$ & $21 \%$ & $79 \%$ \\
\hline Germany $(\mathrm{n}=267)$ & $17 \%$ & $76 \%$ & $4 \%$ \\
\hline Macedonia $(\mathrm{n}=13)$ & $31 \%$ & $46 \%$ & $15 \%$ \\
\hline Poland $(\mathrm{n}=14)$ & $36 \%$ & $7 \%$ & $57 \%$ \\
\hline Spain $(\mathrm{n}=20)$ & $5 \%$ & $25 \%$ & $70 \%$ \\
\hline Switzerland $(\mathrm{n}=23)$ & $18 \%$ & $0 \%$ & $87 \%$ \\
\hline
\end{tabular}

Table 2. Age of survey participants' learners.

\footnotetext{
${ }^{5}$ In Finland, children are allowed to start a year later and in Switzerland mandatory elementary school starts at age 7, although many children attend kindergarten at age 5 or 6 . In Poland and Macedonia they start school at age 7.
} 
Total percentages for Macedonia (92\%) and Germany (97\%) are less than $100 \%$ because some learners were younger than the categories presented in Table 2. The total percentage for Switzerland (105\%) is over $100 \%$ because the categories in the first question were not distinct from one another. This might also have influenced the age groups reported by the Polish teachers, as several taught in public schools in the daytime and gave additional classes in private language schools in the evenings or at weekends. The respondents in Switzerland taught primarily in higher education (87\%), as in France (79\%). Respondents in Finland tended to be involved in secondary schools (84\%), with only a few respondents teaching in vocational schools or at university. In four of the seven countries a large majority of respondents worked in the public sector: Finland (92\%), France (97\%), Germany (94\%), Spain (81\%). However, in Macedonia, Poland and Switzerland the opposite was true; $77 \%, 75 \%$ and $61 \%$ of respondents, respectively, taught in the private sector in these countries.

To summarise, the majority of participants were female non-native speakers of English. They worked predominantly in the public sector, except in Macedonia, Poland and Switzerland. Participants in Switzerland primarily taught adults; participants in France and Spain primarily taught adults and a smaller percentage of young adults; respondents from Finland, Germany and Macedonia mostly taught young adults and, to a lesser degree, children. In Poland participants' learners came from the two ends of the age spectrum.

\section{Results and Analyses}

The survey results are presented in three parts, referring to what teachers from seven countries said about: the training they received to teach English pronunciation; what happens inside the classroom (teaching materials and methods, evaluation of pronunciation); and what happens outside the classroom (type and frequency of learners' exposure to English in society at large).

\section{Training Received to Teach English Pronunciation}

In terms of their general level of education, respondents in only two countries held specific EFL qualifications. In Switzerland, 13 described themselves as TEFL-trained ${ }^{6}$ with two having PhDs. The majority (94\%) of Finnish respondents had at least an MA degree, as EFL subject teachers are expected to hold an MA degree in English with pedagogy as a minor subject in the degree. The Polish respondents were either recent graduates or were still doing MA courses. All the Macedonian respondents held BA degrees, one had an MA degree, and one had a CPE certificate. In the case of Spain, with the exception of one teacher working in the private sector who had not graduated, all respondents had university degrees and a further 25\% also had an MA or PhD. In France, over half of the respondents had passed the CAPES or the Agrégation (France's national competitive exams for recruiting teachers ${ }^{7}$ ), and many other different levels and types of qualifications were listed. Of the remaining six countries referred to in this article, Germany is the only other one which has a similar competitive exam for recruiting school teachers. Each federal state has independent responsibility for teacher training, but all states share a system in which prospective teachers for all school types are not allowed to teach until they pass both Erstes Staatsexamen (first state exam, a degree at university) and Zweites Staatsexamen (second state exam, teacher training in schools).

This section of the survey began with explicit instructions to answer in relation to training they had received specific to teaching English pronunciation. Nonetheless, many of the respondents clearly saw their undergraduate courses in phonetics as part of their training, and described how they themselves had practiced their own pronunciation. The three questions concerning pronunciation training were:

- Please tell us how much training you received specific to teaching pronunciation. Feel free to mention any period of time (hours, months, years, etc.).

- Please explain the content and/or style of the training you received. Feel free to mention types of courses, approaches, etc.

- In relation to pronunciation, please rate the teacher training you received from 1 to 5 , with 1 as "extremely poor" and 5 as "excellent".

\footnotetext{
${ }^{6}$ For example, having a DipTEFL, CELTA, MEd in TESOL.

${ }^{7}$ One cannot take these exams without first completing an undergraduate degree and, since 2011, a 2-year Master's programme has to be completed before one is allowed to teach.
} 
The first two questions were open-ended, and qualitative content analysis of the responses revealed three recurrent topics: (1) phonetics/pronunciation courses/modules; (2) pronunciation module in a more general TEFL course or MA programme; and (3) little or no training. For example, in Switzerland the replies about quantity varied from "none at all" (3 respondents), to ten references to training during CELTA courses, to a very specific description of a 16-week course during a Bachelor's programme (which did not address the teaching of pronunciation but only "learning the symbols"). Amongst the younger and less-experienced teachers in Poland, less than a quarter of respondents (19\%) said they had received formal training in teaching pronunciation. Similar comments were found in the French responses, where the range of ages and experience was greater (age range 23 to 69 years old, teaching experience 1 to 44 years). In their comments, 19 of the 52 French respondents who replied to this open-ended question said they had very little or no training and mentioned only the phonetics classes they had received as undergraduates. Nine of the 52 mentioned training they had received at conferences, workshops, etc., which they had attended since becoming teachers.

A slightly more encouraging picture emerged when teachers were asked to rate the teacher training they had received on a 5-point Likert-scale, where 5 was "excellent" (Table 3).

\begin{tabular}{|c|c|c|}
\hline & Average & Mode \\
\hline Finland (n=81) & 3.16 & 4 \\
\hline France (n=54) & 2.63 & 1 \\
\hline Germany (n=278) & 2.86 & 3 \\
\hline Macedonia (n=17) & 3.24 & 4 \\
\hline Poland (n=14) & 3.21 & 4 \\
\hline Spain (n=25) & 3.00 & 4 \\
\hline Switzerland (n=16) & 2.81 & 4 \\
\hline
\end{tabular}

Table 3: "In relation to pronunciation, please rate the teacher training you received from 1 to 5 , with 1 as "extremely poor" and 5 as "excellent"."

In Finland, Macedonia and Poland the average score was above 3. Although none of the averages are particularly high, the modes ${ }^{8}$ reveal that overall respondents rated their teacher training positively. The exception is France which had by far the lowest mode (1) of all the countries, even though its average score was not very different from Germany's or Switzerland's. In general, the modes show a relatively rosy picture. The modes provide an important nuance to the analysis, as do comments made in open-ended questions from the survey and follow-up interviews, where respondents clearly emphasised that they had been taught about pronunciation - or had worked on improving their own pronunciation - but had not been taught how to teach pronunciation. One described a university module as "...theoretically based without any practical classroom application. This gave me a good overview of the IPA and the different terms related to the biology of the mouth along with the restrictions some speakers may have". Another respondent, in France, said: "We had a few classes about the pronunciation of English, intonation etc. but just the theory and no actual demonstration of how to teach them". One respondent in Germany echoed this sentiment: "I studied at times of the former GDR that is why I didn't get much training ... but I had an excellent phonetics teacher". However, as another aptly concluded: "knowing about something is certainly not the same as knowing how to teach it".

Asked to describe the content and/or style of their training, numerous non-native English speaking teachers (native-speakers were less than $10 \%$ of total respondents) explained how their undergraduate courses were aimed at improving their own pronunciation through phonetics and transcription, repetition and drills, discussion exercises, reading aloud, and listening tasks. Training in a language lab was mentioned frequently by respondents in all countries except Switzerland, as were theoretical lectures and

\footnotetext{
${ }^{8}$ The mode shows where most scores are concentrated.
} 
various types of exercises for practicing phonetic symbols and phonemic transcription, English sound formation and categorization, basic phonetic and phonological rules, and different types of intonation patterns. In addition to apparent confusion between "phonetics" and "pronunciation", many respondents did not distinguish between their undergraduate education and their actual teacher training. This may be for the simple reason that the only experience on which they could draw was their undergraduate phonetics and phonology lectures.

However, some respondents in Germany described practical techniques they acquired during teacher training:

- "working in a language lab, listen and repeat exercises (individual or in groups) with teacher or $C D$, ways of introducing new words and their pronunciation, ways of controlling the correct pronunciation"

- "instructions on how to teach pronunciation to children in our 'Seminar' (teacher training group)" In this respect, their comments are similar to those of the respondents in Switzerland who said, for example, that they "watched teachers on DVDs" or that "A speaker comes and then in groups we practice their teaching methods." Some referred to specific universities, books, biographies and authors, or claimed to be self-taught:

- "Mainly gleaned from workshops and using course books."

- "... CELTA required a written paper on teaching it. The rest has been basically self-taught."

The self-taught teacher appears again in the Spanish data, where $28 \%$ of the respondents indicated having received no, or practically no, formal training and a further $22 \%$ described themselves as self-taught. Only three respondents had received further training or taken subsequent courses after university. A few teachers in Macedonia mentioned additional training but it was related to English teaching in general and not specifically pronunciation. It is worth noting that Macedonian teachers gave the highest average ratings with regard to their training to teach pronunciation, and one of them highlighted its necessity: "I believe the teacher should be very well trained in order to be good at teaching pronunciation".

Concomitantly, it was widely felt that having good pronunciation is sufficient for teaching pronunciation, however it is acquired:

- "I went to study abroad, one year in Australia. Best pronunciation training ever"

- "None at all, but I lived in GB for a year"

- "Professors at the university and teacher trainers presumed that if one is able to pronounce correctly, they will somehow be able to make the children pronounce correctly, too"

These comments confirm the tenacity of two commonly held misconceptions about pronunciation: that studying phonetics translates into being able to teach pronunciation and that living in an English-speaking country necessarily results in better pronunciation. The first misconception has had the knock-on effect of frightening many teachers away from pronunciation work in the classroom. The follow-up interviews with French participants provide insight into some teachers' reticence to deal with pronunciation. One participant has "avoided doing pronunciation" for her entire career and another spoke of "a vicious circle": she doesn't feel she truly understands the phonetics and phonology of English but, as she doesn't feel obliged to teach pronunciation, she isn't bothered about learning more. Another described herself as "wandering around in the dark".

To conclude, participants' comments reveal that many, if not most, appear to be amateurs when it comes to teaching pronunciation, as they have received little or no specific training in how to teach pronunciation. However, most of the non-native English-speaking respondents had usually received training in improving their own pronunciation. Whatever training they had received was often judged positively. Perceptions of teaching pronunciation continue to evoke powerful metaphors and strong representations.

\section{Inside the Classroom: Materials, Teaching Methods and Assessment}

\section{Materials}

Teachers were asked about published and on-line materials, as well as about their use of language laboratories and/or portable sound players. The results indicate that, unsurprisingly, use of cassettes and VHS-format videos is declining, whereas CDs and DVDs are widely used. On average, $84 \%$ of participants said they used DVDs but this percentage was lower in France and Poland (60\%). Use of textbooks and dictionaries was quite varied, with participants in France indicating significantly less use (49\% and 69\%), compared with the other six countries (means of $97 \%$ and $90 \%$ ). 
A separate question asked about the use of various types of on-line resources. The most popular choice was specific language learning websites (76\%), such as Voice Of America or BBC Learning English, followed by sites not specifically intended for this purpose, such as YouTube (64\%). Pre-existing modules or courses and podcasts were chosen by $45 \%$ and $37 \%$ of respondents, respectively. All of these figures will undoubtedly evolve as the use of a wide variety of on-line resources (e.g. blogs, forums, MOOCs) becomes more prevalent.

It is a positive sign that over half $(58 \%)$ of respondents indicated that they have sufficient access to technical help, with Spain having the lowest score (30\%) and Finland the highest (78\%). Access to a language lab varied from $7 \%$ in Germany to $100 \%$ in Switzerland. Labs tend to be multimedia and/or digital, although cassette-based labs are still in use everywhere except in Switzerland. Portable sound players are also widely available, including tape, $\mathrm{mp} 3, \mathrm{CD}$ and "other" types. Use of labs or portable players is quite varied, with infrequent use of a separate language lab often being offset by use of a portable sound player.

\section{Teaching Methods}

In terms of teaching methods, questions focused on English language use in the classroom, the amount of time spent on pronunciation work, use of ear training and phonetic symbols. In addition to being broached in short quantitative questions, these topics arose in open-ended questions not necessarily included in this section of the survey. As the comments shed light on the statistics, the two are blended in the following analysis.

One important methodological difference between countries concerns the language used in the classroom, as this reflects differences in individual opinions, in national language policy and in societal priorities. In the 2012 First European Survey on Language Competences report (ESLC; European Commission, 59), on average respondents indicated that they "usually" use the target/foreign language (although students' estimations of teachers' use are slightly lower). The question on the EPTiES survey was "Approximately how much of the time is a language other than English spoken in the classroom?" The results confirm those of the ESLC, as $60 \%$ of EPTiES participants said they used another language only 0$20 \%$ of the time. In Switzerland, an explicitly plurilingual society, 35\% of the respondents stated that they never use another language, compared to only $17 \%$ in neighbouring France and an overall average of $8 \%$. Half of the participants in Spain and 52\% in Switzerland claimed to use another language only 1-10\% of the time (compared to 31\% overall), whereas 37\% in France made this claim. While Switzerland's low use of a language other than English might be partly attributed to a supposed sensitivity to plurilingual issues, this probably does not explain the Spanish results. The fact that participants in France indicated more frequent use of another language contradicts the findings of the larger ESLC study.

The majority of respondents (79\%) indicated that they devote up to a quarter of their weekly teaching time to teaching pronunciation, although one teacher stated that "apart from some random pronunciation exercises (demonstrating pronunciation of the new words mainly), I don't think that more than 5\% of the teaching time needs to be devoted to pronunciation.". Overall, 54\% of respondents from the seven countries say that devoting a quarter of weekly class time is sufficient, and $31 \%$ indicated that they would like to devote up to half. Half the Polish participants felt that the minimal amount of pronunciation practice (from 1 to 25\%) was sufficient and two of them commented: "I believe Polish students don't have problems with pronunciation, they are easily understood." and "My students are more interested in communication than pronunciation." In Macedonia, the participants' comments showed that communication clearly takes priority over correct pronunciation: English "needs to be learnt" because it is "the language of global trade" and "all information is in English". These teachers were voicing the idea that communication is the goal of learning English for their learners; thus pronunciation as a skill is a lower priority (Henderson et al. 2012).

Comments made it clear that even when pronunciation seems teachable it may not be perceived as learnable, as one teacher commented in response to the question about the amount of time spent teaching pronunciation: "I enjoy teaching pronunciation, the difficult part is that the students find it difficult to grasp. It's a difficult subject." In an implicit reference to the teachability-learnability debate, another participant argued that "the phoneme is too abstract and the syllable is more intuitive. So I teach only the schwa and work on lexical stress and weak vowels at the syllable level."

A large majority of the respondents indicated that they use ear training (73\%). Individual percentages for each country are given in Table 4: 


\begin{tabular}{|c|c|c|c|c|c|c|}
\hline FI $(\mathbf{n}=\mathbf{9 2})$ & FR $(\mathbf{n}=\mathbf{5 2})$ & DE $(\mathbf{n}=\mathbf{3 2 6})$ & MK $(\mathbf{n}=\mathbf{2 4})$ & PL $(\mathbf{n}=\mathbf{1 6})$ & $\mathbf{E S ~}(\mathbf{n = 2 7})$ & CH (n=24) \\
\hline $67 \%$ & $75 \%$ & $82 \%$ & $83 \%$ & $63 \%$ & $74 \%$ & $67 \%$ \\
& & & & & & \\
\hline
\end{tabular}

Table 4: "Do you use ear training?" (YES + SOME replies combined)

Thus, ear training seems to be an uncontroversial and popular choice across the board. On the other hand, use of phonetic symbols is a more contentious issue which arose frequently in open-ended replies. For example, one teacher argued that "Unless they become English language teachers, they will not really need to know how to write them. They will only need to be able to recognise them." Another participant was quite certain that "it helps the learners to get a feeling for the differences in writing and speaking" whereas another said "Parents are paying for English communication - not the learning of symbols".

Two questions asked participants if they teach their student to write or to recognise phonetic symbols (Table 5).

\begin{tabular}{|c|c|c|c|c|c|c|c|}
\hline & $\begin{array}{c}\text { FI } \\
(\mathrm{n}=92)\end{array}$ & $\begin{array}{c}\text { FR } \\
(\mathrm{n}=52)\end{array}$ & $\begin{array}{c}\mathrm{DE} \\
(\mathrm{n}=329)\end{array}$ & $\begin{array}{c}\text { MK } \\
(n=24)\end{array}$ & $\begin{array}{c}\text { PL } \\
(n=16)\end{array}$ & $\begin{array}{c}\text { ES } \\
(n=27)\end{array}$ & $\begin{array}{c}\text { CH } \\
(n=26)\end{array}$ \\
\hline 苋 & $96 \%$ & $81 \%$ & $84 \%$ & $92 \%$ & $88 \%$ & $85 \%$ & $50 \%$ \\
\hline & $\begin{array}{c}\text { FI } \\
(n=92)\end{array}$ & $\begin{array}{c}\text { FR } \\
(\mathrm{n}=52)\end{array}$ & $\begin{array}{c}\mathrm{DE} \\
(\mathrm{n}=328)\end{array}$ & $\begin{array}{c}\text { MK } \\
(n=24)\end{array}$ & $\begin{array}{c}\text { PL } \\
(n=16)\end{array}$ & $\begin{array}{c}\text { ES } \\
(n=27)\end{array}$ & $\begin{array}{c}\text { CH } \\
(n=26)\end{array}$ \\
\hline 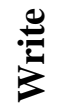 & $23 \%$ & $54 \%$ & $28 \%$ & $63 \%$ & $56 \%$ & $41 \%$ & $8 \%$ \\
\hline
\end{tabular}

Table 5: "Do you teach your learners to RECOGNISE/WRITE symbols?" (YES + SOME replies combined)

In all seven countries, respondents were less likely to teach their learners to write symbols (average $40 \%$ ) rather than to recognise them (average 82\%). Learners' ages might explain some of the variation in the results, as teachers are perhaps more likely to teach symbols to older learners. However, in Switzerland only $50 \%$ of the participants claimed they taught their learners to recognise symbols and only $8 \%$ indicated that they taught learners to write them, even though most of them worked with learners aged 17 and older. On the other hand, seventy-nine percent of respondents in France indicated having learners mainly in this age category and the majority indicated teaching students to recognize $(81 \%)$ as well as write (54\%) symbols. The greatest difference in responses between teaching students to recognise and to write symbols was in Finland ( 73 percentage points). This could be due in part to the fact that $31 \%$ of participants in Finland indicated that their learners were aged just 6-12 years.

The quantitative data are thought-provoking but the qualitative comments revealed a more complex set of influences on decision-making. In written comments, four common themes appeared:

1. Language-specific features

2. The age of learners

3. A lack of self-confidence with symbols and with technology

4. The need to prioritise during limited contact hours

Language-specific features influence teachers' decisions, but this seems logical given the weight attributed to contrastive analysis. Participants referred to teaching symbols only for those sounds which do not exist in the learners' native language or which are "difficult" (but this term was not explained). Whether the symbols were taught or not was often conditioned by the age of the learners. Of university-level learners one participant wrote, "I teach the symbols which are most pertinent for their pronunciation difficulties (vowels, diphthongs) so that they can check pronunciation, connect sounds/spelling etc." In contrast, a few participants saw it as a futile investment with older students, as pronunciation was already fossilised: "it's too late in their studies". Teachers working with younger learners often linked teaching symbols to work on the spelling-pronunciation mismatch of English. 
In terms of confidence in one's professional skills, many respondents felt that a teacher has to master the IPA in order to teach pronunciation; as they themselves are not experts, they doubted their ability to teach it. One teacher described how she was "not at home with them". In reality, even though it is undoubtedly quite useful to know the IPA, many, such as Fraser (2001) and Gilbert 2010) claim it is entirely possible to work effectively on pronunciation without using symbols. This is also asserted by those who successfully use the Silent Way approach (Gattegno 1972 and 1976; Herry-Bénit 2011) and other non-imitative approaches (e.g. Acton 1984 or Messum 2007 and 2012). Survey participants often mentioned symbols in the same breath as technology when justifying why they do or do not teach pronunciation. For example, several respondents attributed their reticence to teach pronunciation to a lack of technological skills, being convinced that pronunciation cannot be taught without technology, be it in the form of a language lab, software or Internet-based resources. Although technology can be extremely useful, many would argue that it is not essential for teaching pronunciation, so a lack of technology skills should not deter teachers. Technology in the learners' hands also influences prioritizing. According to one participant, "It's very too- time-consuming. Now they use on-line dictionaries and listen to the pronunciation of words". Several participants referred to Internet dictionaries' clickable sound files. A desire to promote autonomy was also given as a reason for teaching at least symbol recognition. For example, one participant argued that learners "are independent and with a good dictionary should be able to pronounce any word, known or unknown". One went so far as to claim that learning the symbols promotes "rigorous reasoning", whereas another asserted "This is not an efficient way of teaching pronunciation. I have better."

\section{Assessment}

Pronunciation assessment was explored in a series of questions. First, teachers were asked whether they base assessments on an established national or international scale. In every country, a minority of the respondents replied affirmatively to this YES-NO question (Table 6):

\begin{tabular}{|c|c|c|c|c|c|c|}
\hline FI $(\mathbf{n = 8 4})$ & FR $(\mathbf{n = 5 2})$ & DE $(\mathbf{n = 2 9 1})$ & MK $(\mathbf{n}=\mathbf{1 8})$ & PL $(\mathbf{n = 1 4})$ & $\mathbf{E S ~}(\mathbf{n = 2 6})$ & $\mathbf{C H}(\mathbf{n}=\mathbf{2 5})$ \\
\hline $23 \%$ & $31 \%$ & $9 \%$ & $11 \%$ & $0 \%$ & $27 \%$ & $36 \%$ \\
\hline
\end{tabular}

Table 6: "Are any of your evaluations linked to an established scale, for example national or international scale?" (YES replies)

The highest percentages of established scale use were found in Switzerland (36\%) and in France (31\%), with Spain (27\%) and Finland (23\%) not far behind. That none of the participants in Poland and so few in Germany and Macedonia refer to an established scale is surprising and cannot be explained simply by looking at the age of learners. Participants in Germany and Macedonia taught similar age ranges (mostly young adults and a few teach children) but participants in Poland taught both ends of the age spectrum. Economic factors may play a role (e.g. lack of pre- or in-service training in how to use a scale), but this probably does not explain the low German figure.

Of those who did use an established scale, the vast majority $(86 \%)^{9}$ referred to the Common European Framework of Reference (CEFR; Council of Europe 2001) in a related open-ended question ${ }^{10}$. This would seem to be good news, as use of the Framework is relatively rare throughout Europe (European Commission 2012, 65) and an ongoing poll confirms this". It asks "How well do you understand the Common European Framework of Reference for Languages?" To date, out of 3291 votes, 14\% chose "I have no idea what the CEFR is" and 31\% chose "I know what it is, but I'm not very confident with it." Almost half (43\%) chose "I'm fairly confident, but would like more help with it", and a mere $12 \%$ chose "I'm an expert". In the EPTiES survey, amongst the minority who indicated that they did refer to an established scale, 100\% of respondents in France and in Spain mention the CEFR. For France, this is reassuring because more than $60 \%$ of teachers in French primary and secondary schools have received specific training in using it (European Commission 2012, 65). Percentages were also quite high for Switzerland (89\%), Germany (88\%) and Finland (79\%), whereas in Macedonia only $11 \%$ of respondents mentioned the CEF and $0 \%$ in Poland did. Failure to use the CEFR in relation to pronunciation might also

\footnotetext{
${ }^{9}$ See also Kirkova-Naskova et al. (2013).

10 "If yes, please state which scale is used as a reference scale for your evaluations, eg. ACTEFL, CEF, etc.".

${ }^{11}$ Figures from June 2, 2014 from the on-line survey available at the Cambridge University Press sponsored Website "Cambridge English Teacher" (http://www.cambridgeenglishteacher.org/).
} 
be linked to the fact that the descriptors do not directly refer to pronunciation, only to fluency and ease. For example, the descriptor for Spoken Interaction at Level B2 is: "I can interact with a degree of fluency and spontaneity that makes regular interaction with native speakers quite possible" (Council of Europe 2001, 12). A few participants mentioned international certifications $\left(B U L A T S^{12}, I L R^{13}\right.$ or TOEFL).

In a set of questions about teaching context, a simple YES-NO question explicitly asked whether or not learners were streamed: "Are groups streamed by language competence level?" (Table 7):

\begin{tabular}{|c|c|c|c|c|c|c|}
\hline FI $(\mathbf{n}=\mathbf{7 7})$ & FR $(\mathbf{n}=\mathbf{5 2})$ & DE $(\mathbf{n = 2 6 6})$ & MK $(\mathbf{n}=\mathbf{1 3})$ & PL $(\mathbf{n = 1 4})$ & ES $(\mathbf{n = 2 0})$ & CH (n=24) \\
\hline $8 \%$ & $44 \%$ & $10 \%$ & $69 \%$ & $36 \%$ & $55 \%$ & $83 \%$ \\
& & & & & & \\
\hline
\end{tabular}

Table 7: “Are groups streamed by language competence level?”(YES replies)

Overall, streaming does not seem to be very common, as out of the 466 participants who answered this question only $9 \%$ answered YES and $6 \%$ answered SOME $^{14}$. It is crucial here to factor in the average age of the survey participant's learners, as typically younger learners are not streamed, whereas those in secondary and higher education tend to be streamed to some extent. Therefore, it is not surprising that $83 \%$ of participants in Switzerland, most of whom taught adults, indicated streaming is used. In Finland, Germany and Macedonia the participants mostly taught young adults and, to a lesser degree, children, but the extreme difference between their responses (8\%, 10\% and 69\%) suggest that larger forces are at work. The decision to stream learners is not solely dependent on age and might also reflect the underlying philosophies of an educational system.

Questions about the practical aspects of assessment explored when it is carried out and via which types of activities. Of the two questions about assessment timing, one YES-NO question explored whether teachers make use of diagnostic assessments at the beginning of the course, and another multiple-choice question asked whether they do assessment only at the end of a course, during the course to help the learning process (continuous assessment), or whether they combine the two (during and at the end). The results for these two questions are given in Table 8:

\begin{tabular}{|c|c|c|c|c|}
\hline $\begin{array}{c}\text { Diagnostic } \\
\text { before a course } \\
(\mathrm{n}=513)\end{array}$ & $\begin{array}{c}\text { Only at the end } \\
\text { of a course }\end{array}$ & $\begin{array}{c}\text { During a } \\
\text { course } \\
(\mathrm{n}=511)\end{array}$ & $\begin{array}{c}\text { Combination } \\
\text { of both }\end{array}$ & Other \\
\hline $31 \%$ & $6 \%$ & $49 \%$ & $33 \%$ & $13 \%$ \\
\hline
\end{tabular}

Table 8. "Do you do an initial diagnostic?" and "Do you evaluate your learners' pronunciation at the end of the course and/or during the course?"

In answer to the question about the use of diagnostic assessments before a course, $31 \%$ of respondents indicated doing such assessments, with figures ranging from 67\% in Switzerland and 64\% in Spain to $26 \%$ in Germany and 23\% in Finland. Respondents may have indicated less use of diagnostic assessments simply because it is not an evaluation requirement.

In general, evaluating learners only at the end of a course seems to be quite rare (6\% on average, with no respondents in Macedonia, Spain or Switzerland). However, 21\% of surveyed teachers in Poland said they evaluated learners only at the end of a course and $57 \%$ of them indicated that they use a combination of final and continuous assessment. Assessment during the course seems to be the most common choice, with an overall average of $49 \%$ with the highest percentages for participants in Finland (45\%), Germany (55\%) and Macedonia (58\%). Overall, a combination of continuous and end-of-course assessment is apparently also used (average 33\%), especially in Spain where the figure rises to 63\%. In France and Switzerland, all three assessment types were almost equally chosen, implying that these teachers diagnose problems, monitor their students' progress during the course and evaluate it at the end.

\footnotetext{
${ }^{12}$ BULATS, or Business Language Testing Service, is a series of computerised language tests.

${ }^{13}$ The ILR (Interagency Language Roundtable) refers both to the test and the scale used by the American government to evaluate the language skills of its employees.

${ }^{14}$ In an open-ended question which followed the YES-NO question, a tiny minority ( 7 out of 458 respondents) referred to using the CEFR descriptors. The question was: "If learners are streamed into groups by levels, how is their level assessed?"
} 
The respondents were also asked to choose from a list the activities they use for diagnostic, formative and evaluative assessments (Table 9).

\begin{tabular}{|l|c|c|c|}
\hline \multicolumn{1}{|c|}{ Type of assessment } & $\begin{array}{c}\text { Diagnostic } \\
\text { Type of activity }\end{array}$ & $\begin{array}{c}\text { Formative } \\
(\mathbf{d u r i n g} \text { a course) } \\
(\mathbf{n = 5 2 5})\end{array}$ & $\begin{array}{c}\text { Evaluative } \\
\text { (at the end of a course) } \\
(\mathbf{n = 5 3 5 )}\end{array}$ \\
\hline Oral performances & $28 \%$ & $78 \%$ & $70 \%$ \\
\hline Reading aloud & $28 \%$ & $73 \%$ & $56 \%$ \\
\hline Listening comprehension & $23 \%$ & $65 \%$ & $58 \%$ \\
\hline Oral exams in pairs & $15 \%$ & $46 \%$ & $53 \%$ \\
\hline Individual oral exams & $15 \%$ & $37 \%$ & $42 \%$ \\
\hline Written work & $9 \%$ & $18 \%$ & $18 \%$ \\
\hline Other & $5 \%$ & $11 \%$ & $7 \%$ \\
\hline
\end{tabular}

Table 9. Tasks used in the assessment of pronunciation skills

Amongst the types of assessment activities selected, the most popular were oral performances (presentations, sketches, dialogues), closely followed by reading aloud and listening comprehension. In both formative and evaluative assessments there was a distinct tendency to test students in pairs (46\% and $53 \%$, respectively). This may be due in part to the influence of training to become a Cambridge examiner or training received during a CELTA or DELTA ${ }^{15}$ course. The data highlight the fact that written tasks (e.g. transcription) are used less frequently compared to the more popular tasks (9\%, 18\% and $18 \%$ respectively). This brings to light an intriguing mismatch, in that the majority of the teachers were trained in transcription but do not make use of it in evaluating learners' performance. This may be related to the stated communicative objectives of many European curricula. Although the European Union makes no attempt to impose a teaching method for foreign languages, it does seek to promote "a broad holistic approach to teaching in which emphasis is placed upon communicative ability and multilingual comprehension. The great majority of educational systems issue recommendations to attach equal emphasis to all four communication skills" (European Commission, 2012, 82). Therefore, it seems logical that teachers would prefer to assess learners' pronunciation in situations resembling real-life communication rather than via transcriptions, for example. This is all the more so if evaluation is done globally.

Finally, it should be noted that the Council of Europe's European Language Portfolio (ELP) was not included in the list of activities to choose from, even though it was explicitly developed and promoted as a self-assessment tool that could also help improve meta-linguistic reflection. We expected it to be mentioned in the open-ended questions, as Swiss universities and vocational schools, for example, often use it ${ }^{16}$, but no one referred to it. This lends credence to the ESLC report, according to which fewer than $25 \%$ of European teachers use the $\operatorname{ELP}(2012,65)$.

\section{Outside the Classroom: TV \& Cinema, Face-to-Face \& On-Line interactions, Private Tuition}

It is also important to gauge levels of exposure to English outside the classroom, where learners can practise (or at least read or listen to) a foreign language. To this end, two questions focussed on availability and use:

- Are students exposed to English outside the classroom via ? (four options to choose from): Yes, Some, No, I don't know.

- Estimate how often your learners are exposed to English outside the classroom via the following sources: (five options to choose from): Never, Rarely, Sometimes, Frequently, I don't know.

It must be stressed that the results reflect teachers' appraisals or opinions of their students' habits; the information does not come directly from the learners and must, therefore, be treated with caution. Participants chose from a list of possibilities: subtitled television programmes, subtitled films in the cinema, private tuition, face-to-face contact and on-line resources such as e-mail, forums, chatrooms. The choices

\footnotetext{
${ }^{15}$ The DELTA (Diploma in English Language Teaching to Adults) is one of several diplomas available via Cambridge University and certifies people as apt to teach English as a foreign language. It can only be taken by teachers with two years' teaching experience.

${ }^{16}$ See data provided by the Conférence suisse des directeurs cantonaux de l'instruction publique http://www.ides.ch/dyn/15540.php
} 
did not include Internet streaming of films and television series-, or on-line and video games but future studies should take these media into account, as high-speed Internet access, Web 2.0 technology and 4G smartphone services are becoming widespread. According to a survey by the Institut français d'opinion publique (IFOP 2010), 37\% of French internet-users download illegally. Some of this is probably due to people's impatience with the length of time it takes for official dubbed versions of their favourite television series to become available. Sockett's 2011 study of French students' downloading habits revealed that $60 \%$ of those surveyed downloaded films or television series at least once a month. In addition, a recent survey in Finland shows that young Finns regularly consume English language media (Leppänen et al. 2011).

\section{Television \& Cinema}

The media are an obvious field of action for national language policy. Legislation affects everyday language use and, as a consequence, language learning. In 2008, in a paper to the European Parliament ${ }^{17}$, the European Commission recommended the use of subtitles. The European Union has also passed several laws in order to promote the languages of member states, including the "Télévision sans frontières" (TSF) directive. First issued in 1989 and renewed in 2007, this directive obliges member states to ensure that at least $51 \%$ of all television programmes, including those broadcast via satellite, Internet, etc., are made in the country. Paradoxically, the immediate effect in France has been that English-language series and films are systematically dubbed. However, and despite massive state funding of the French film industry, the majority of films shown in French cinemas are foreign - mostly American. This is arguably the case in most of the countries in which EPTiES participants work, as the European average for domestic film market share is only 13\% (Suomen elokuva Säätiö 2013, 5). According to a 2012 report from the Finnish Film Foundation, 58\% of Finland's film market is taken by American films, compared with $27 \%$ for Finnish films (ibid.). Domestic films fare even worse in Switzerland, occupying only 3\% of the market in 2008, compared with a $63 \%$ market share for American films ${ }^{18}$. Questions about media in EPTiES were presented as follows (Figure 1):

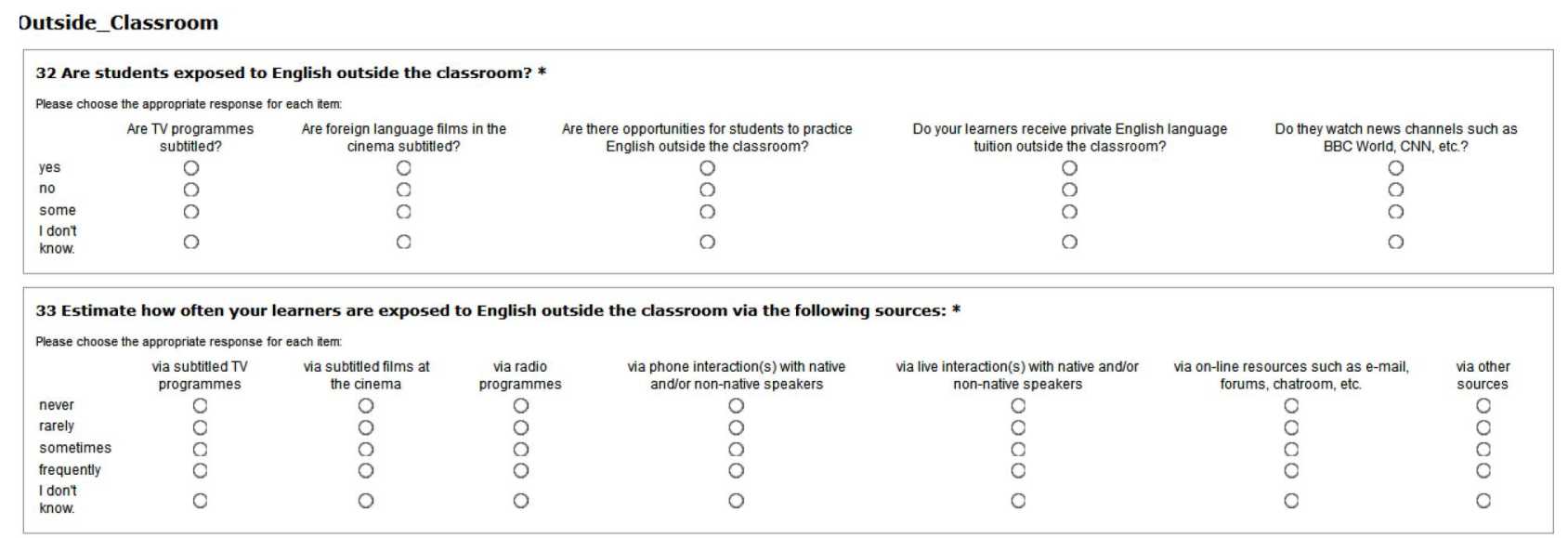

Figure 1: How EPTiES presented questions about exposure to English.

Table 10 summarizes the results of the survey questions concerning the availability of subtitled TV programmes.

\begin{tabular}{|c|c|c|c|c|c|c|}
\hline FI (n=96) & FR (n=60) & DE $(\mathbf{n = 3 4 4})$ & MK $(\mathbf{n}=\mathbf{2 9})$ & PL $(\mathbf{n}=16)$ & ES $(\mathbf{n}=\mathbf{2 9})$ & CH (n=26) \\
\hline $98 \%$ & $49 \%$ & $24 \%$ & $97 \%$ & $57 \%$ & $31 \%$ & $51 \%$ \\
& & & & & & \\
\hline
\end{tabular}

Table 10: "Are students exposed to English outside the classroom via TV programmes subtitled in English?" (YES + SOME replies combined)

According to the vast majority of participants in Finland and Macedonia (98\% and 97\%), learners have access to subtitled TV programmes. The lowest percentages of positive answers for subtitled TV-

17 See the 2008 paper on multilingualism: "Multilingualism: an asset and a commitment", available at http://europa.eu/legislation_summaries/education_training_youth/lifelong_learning/ef0003_en.htm.

18 See a "Media Landscapes" report by Meier on the European Journalism Centre website: http://ejc.net/media_landscapes/switzerland. 
programme access came from participants in Germany (24\%) and Spain (31\%). In France, Switzerland and Poland approximately $50 \%$ of participants responded positively to this question. For Germany, Berentzen (2009) noted that it is rare for films and television programmes to be subtitled. Where subtitles are provided, they are "primarily intended for the hearing-impaired. But in Scandinavian countries, the option of viewing productions with subtitles in one's respective native tongue is available. In this way, immigrants are supported in their efforts to learn their new country's language" (ibid.). Subtitling probably plays a role in helping Scandinavians to learn each others' languages, thus promoting a degree of regional multilingual awareness. The idea of using television to improve language learning recently motivated the French national channel France 2 to show an English-language television series every Monday night in English with French subtitles. According to hdnumerique.com, a media industry website, "watching films in their original language encourages the learning of English. - ...- This is part of the national channel's desire to favour this learning." ${ }^{\prime 19}$ Perhaps such a change in policy will help improve French students' scores on foreign language comprehension tests, which are often amongst the lowest in Europe (Bonnet 2002). It must be said that successive French governments have actively tried to protect the French language, the most well-known example being the Toubon $\mathrm{Act}^{20}$ of 1994, which states that "the French language is a fundamental element of the personality and heritage of France" and that it is "the language of teaching, of work, of exchanges and of public services". Continuing in the same vein, recent laws include the 2010 decree that one of the official missions of French media is "the defense and illustration of the French language and culture" ${ }^{21}$.

Conversely, Switzerland's multilingual reality and language policy may explain why only $51 \%$ of the EPTiES participants in Switzerland indicated that subtitled television programmes provided exposure to English. Quite simply, the Federal Radio and Television Act of 24 March $2006^{22}$ clearly requires the Swiss Broadcasting Corporation (SSR, Société Suisse de radiodiffusion et télévision) to provide programming to the entire populace in the three official languages and at least one radio programme in Romansch. In regions of language contact, broadcasting is in the two languages. Public channels broadcast in the national languages but people may also choose from a wide variety of international channels. The advent of cable and digital TV has been a key development throughout Europe, offering options which simply were not there before. Often viewers can choose either a dubbed or subtitled version. For example, according to a survey of $1^{\text {st }}$ year Spanish university students studying English, 21\% prefer dubbed versions of English language films when available (Levey and Eizaga, forthcoming).

In the cinema, foreign language films may be presented as dubbed, subtitled (in English or other languages) or neither. Table 11 presents the results for the question regarding the availability of Englishsubtitled foreign films in the cinema:

\begin{tabular}{|c|c|c|c|c|c|c|}
\hline FI (n=96) & FR (n=60) & DE $(\mathbf{n}=\mathbf{3 4 4})$ & MK $(\mathbf{n}=\mathbf{2 9})$ & PL $(\mathbf{n}=1 \mathbf{1 6})$ & ES $(\mathbf{n}=\mathbf{2 9})$ & CH $(\mathbf{n}=\mathbf{2 6})$ \\
\hline $99 \%$ & $89 \%$ & $42 \%$ & $97 \%$ & $88 \%$ & $27 \%$ & $85 \%$ \\
\hline
\end{tabular}

Table 11: "Are students exposed to English outside the classroom via subtitled films in the cinema?" (YES + SOME replies combined)

In all the countries, foreign films are subtitled in the local language(s) and perhaps in English. An American film shown in Finland as a "foreign language film" would have Finnish or Swedish subtitles but learners would hear English. In Macedonia, where there is only one national language, foreign films in cinemas are subtitled in Macedonian. In Germany foreign films may be presented in three different ways in cinemas: in their original language (Original Fassung), in their original language with German subtitles (Original mit Untertiteln) or in the original language with English subtitles (Original mit engl. Untertiteln). This variety might explain why only $42 \%$ of the participants in Germany answered affirmatively. However, the key factor in the results to this survey question is not how films are subtitled, but whether they are

\footnotetext{
${ }^{19} \mathrm{http}: / /$ www.hdnumerique.com/actualite/articles/11709-une-option-vost-le-lundi-soir-sur-france-2.html : “visionner des films en VOST a le mérite également de favoriser l'apprentissage de l'anglais. [...] L'opération s'inscrit dans la volonté de la chaîne publique de favoriser l'apprentissage de l'anglais."

${ }^{20} \mathrm{La}$ loi $\mathrm{n}^{\circ}$ 94-665 du 4 août 1994 relative à l'emploi de la langue française, qui reprend et abroge la loi nº $75-1349$ du 31 décembre 1975. Original French phrasing : "La langue française est un élément fondamental de la personnalité et du patrimoine de la France" and "est la langue de l'enseignement, du travail, des échanges et des services publics".

${ }^{21}$ La loi n ${ }^{\circ} 2010-788$ du 12 juillet 2010, "la défense et l'illustration de la langue et de la culture françaises".

${ }^{22} \mathrm{http}: / /$ www.tlfq.ulaval.ca/axl/europe/suisse-fed-loi2006.htm
} 
subtitled or dubbed. In other words, do they provide opportunities to read English or to hear it? In Spain, dubbing is deeply entrenched, going back to Franco's dictatorship when it served as a means of controlling and censoring content. Dubbing is more expensive than subtitling but it is culturally and historically established; this would explain why only $27 \%$ of participants in Spain reported that their learners had access to English via subtitled cinema films. Switzerland juggles with different languages in both subtitles and dubbing; outside of urban centres, films are dubbed in the regional language but in cities, they are shown in their original language with subtitles in two of the official languages. In 2011, 27\% of the 1565 films shown were American films ${ }^{23}$, which means there are opportunities for learners to hear English in Swiss cinemas.

The next question explored to what extent learners make use of these resources, according to their teachers. The results confirm the tendencies noted above (Table 12).

\begin{tabular}{|c|c|c|c|c|c|c|c|c|}
\hline & & $\begin{array}{c}\text { FI } \\
(\mathbf{n = 9 6})\end{array}$ & $\begin{array}{c}\text { FR } \\
(\mathbf{n = 6 0})\end{array}$ & $\begin{array}{c}\mathbf{D E} \\
(\mathbf{n}=\mathbf{3 4 1})\end{array}$ & $\begin{array}{c}\text { MK } \\
(\mathbf{n = 2 8})\end{array}$ & $\begin{array}{c}\text { PL } \\
(\mathbf{n = 1 6})\end{array}$ & $\begin{array}{c}\text { ES } \\
(\mathbf{n}=\mathbf{2 9})\end{array}$ & $\begin{array}{c}\mathbf{C H} \\
(\mathbf{n}=\mathbf{2 5})\end{array}$ \\
\hline $\begin{array}{c}\text { Subtitled } \\
\mathbf{T V}\end{array}$ & $\begin{array}{c}\text { Frequently or } \\
\text { Sometimes }\end{array}$ & $98 \%$ & $39 \%$ & $11 \%$ & $86 \%$ & $38 \%$ & $28 \%$ & $44 \%$ \\
\hline \hline $\begin{array}{c}\text { Subtitled } \\
\text { cinema }\end{array}$ & $\begin{array}{c}\text { Frequently or } \\
\text { Sometimes }\end{array}$ & $91 \%$ & $52 \%$ & $7 \%$ & $61 \%$ & $94 \%$ & $17 \%$ & $68 \%$ \\
\hline
\end{tabular}

Table 12: "Estimate how frequently your learners are exposed to English outside the classroom via subtitled TV programmes/subtitled films at the cinema".

The results for availability of media and frequency of exposure to media are correlated to some extent. Frequency of exposure to English via subtitled TV programmes was estimated to be highest in Finland (98\%) and Macedonia (86\%), whereas it was estimated to be lowest in Germany (11\%) and Spain (28\%). In Poland, only $38 \%$ of participants responded affirmatively, perhaps because the "voice-over" technique is the most popular means of treating foreign programmes on television; one speaker voices all characters' parts. However, this technique is not used in Polish cinemas, which may explain why participants in Poland had the highest levels of affirmative responses (94\%) for frequency of exposure to English via subtitled films in the cinema, ahead of Finland (91\%). The lowest figures for frequency of exposure via subtitled films in the cinema come from participants in Germany (7\%) and Spain (17\%).

To summarise, according to the teachers who participated in the survey, learners in Finland and Macedonia make the greatest use of a great potential for exposure to English via subtitled TV programmes and learners in Finland and Poland make the greatest use of potential exposure via films in the cinema. On the other hand, learners in Germany and Spain will have to rely on other sources to hear or read English, or already do.

\section{Face-to-Face \& On-Line Interactions}

Another key source of English outside the classroom is interactions with other people. In the same series of questions about film and television, participants were asked to estimate how frequently their learners were exposed to English outside the classroom via live interaction(s) with native and/or non-native speakers or on-line resources such as e-mail, forums, chatroom, etc. (see Figure 1) ${ }^{24}$. A sub-category of this data is presented in Table 13, focusing on face-to-face or on-line encounters. It is noticeable that significantly fewer participants in Finland replied to these two questions (only 80, instead of 96 and 92 for television and cinema films), perhaps because most of them taught younger learners. Table 13 presents the results for both questions.

\footnotetext{
${ }^{23}$ See official Swiss government statistics from March 2012 :

http://www.bfs.admin.ch/bfs/portal/fr/index/themen/16/02/01/dos/02/02.html

${ }^{24}$ Other sources such as Skype or MSN were not explicitly mentioned.
} 


\begin{tabular}{|c|l|c|c|c|c|c|c|c|}
\hline & $\begin{array}{c}\text { FI } \\
(\mathbf{n = 8 0})\end{array}$ & $\begin{array}{c}\text { FR } \\
(\mathbf{n = 6 0})\end{array}$ & $\begin{array}{c}\text { DE } \\
(\mathbf{n = 3 4 0})\end{array}$ & $\begin{array}{c}\text { MK } \\
(\mathbf{n = 2 8})\end{array}$ & $\begin{array}{c}\text { PL } \\
(\mathbf{n = 1 6})\end{array}$ & $\begin{array}{c}\text { ES } \\
(\mathbf{n = 2 9})\end{array}$ & $\begin{array}{c}\mathbf{C H} \\
(\mathbf{n = 2 5})\end{array}$ \\
\hline $\begin{array}{c}\text { Face- } \\
\text { to-face }\end{array}$ & $\begin{array}{l}\text { Frequently or } \\
\text { Sometimes }\end{array}$ & $61 \%$ & $35 \%$ & $17 \%$ & $29 \%$ & $38 \%$ & $55 \%$ & $84 \%$ \\
\hline \hline On-line & $\begin{array}{l}\text { Frequently or } \\
\text { Sometimes }\end{array}$ & $88 \%$ & $69 \%$ & $48 \%$ & $82 \%$ & $69 \%$ & $59 \%$ & $68 \%$ \\
\hline
\end{tabular}

Table 13: "Estimate how frequently your learners are exposed to English outside the classroom via faceto-face/on-line interaction with native or non-native speakers."

Overall, on-line opportunities for communicating in English exceed face-to-face, except in Switzerland, which has four national languages (three official ones) but where English is often used as a lingua franca by Swiss people from one language area when they want to communicate with people from another language area. There are also a considerable number of international companies in Switzerland whose inhouse language is English. One might have thought the same to be somewhat true in Germany's powerful economy which includes a large number of international companies, which might expect their employees to be able to communicate in English. Even though the percentage of pupils in vocational schools learning English has increased from 42\% to 52\% (Statistisches Bundesamt 2003 and 2011) it appears that opportunities for practising English face-to-face outside language classes are limited.

Similarly, according to $41 \%$ of Spanish respondents, their learners have few or no opportunities to speak face-to-face with native or non-native speakers and only $10 \%$ said learners have frequent opportunities. Other comments made by participants in Spain confirm a commonly expressed belief, that students have few opportunities to practise their English outside the classroom.

It is interesting to note that in terms of frequency of exposure via on-line opportunities, once again, Finland and Macedonia seem to be "paired up" (88\% and $82 \%$ reporting that exposure occurs "frequently" or "sometimes"). Other data from the EPTiES survey (Henderson et al. 2012) highlighted similarities between the two countries in the perceived status of English, with the importance of English in relation to other languages receiving an average rating of 4.65 (on a Likert scale of 1 to 5) in Finland, and of 4.69 in Macedonia. In their comments, respondents in Finland frequently mentioned the status of English as a global language, and in Macedonia they mentioned the economic and communicative relevance of English of English as a world language. However, one Finnish respondent pointed out that "English is not the only foreign language people should learn". Finland is a country where foreign language skills are highly valued and vast resources are invested in language education. Foreign language skills may be equally valued in Macedonia but the country has fewer public sector resources to devote to language teaching. Despite vast historical, cultural and economic differences between the two countries, on-line opportunities may be fulfilling a role that official outlets for language learning are failing to satisfy.

\section{Private Tuition}

Private tuition, in the form of extra lessons outside the school/university day, provides another way in which learners may be exposed to English. Table 14 presents the combined YES + SOME results for exposure to English via private tuition:

\begin{tabular}{|l|c|c|c|c|c|c|c|}
\hline & FI (n=96) & FR (n=60) & $\begin{array}{c}\text { DE } \\
(\mathbf{n}=\mathbf{3 4 4})\end{array}$ & $\begin{array}{c}\text { MK } \\
(\mathbf{n}=\mathbf{2 9})\end{array}$ & PL (n=16) & ES (n=29) & $\begin{array}{c}\text { CH } \\
(\mathbf{n}=\mathbf{2 6})\end{array}$ \\
\hline $\begin{array}{l}\text { Private } \\
\text { Tuition }\end{array}$ & $10 \%$ & $25 \%$ & $49 \%$ & $79 \%$ & $69 \%$ & $59 \%$ & $19 \%$ \\
\hline
\end{tabular}

Table 14: "Estimate how frequently your learners are exposed to English outside the classroom via private tuition." (YES + SOME replies combined)

There are clear differences between the countries but the causes are not always easy to identify. The lowest figures are from Finland (10\%), Switzerland (19\%) and France (25\%). Although this could be attributed to the measurably high standard of public education in these countries or to a perception of its quality as high, this is not necessarily the case. As Oller and Glasman point out in their study of private tutoring in France: "private tutoring is not the result of deteriorating teaching standards. It is mainly the result of new academic stakes, due to rising competition between schools and between students within 
school" $(2013,78)^{25}$. The countries where survey participants indicated the highest recourse to private tuition are Macedonia (80\%), Poland (69\%) and Spain (59\%). The participants from Macedonia and Poland, however, did not provide their insights as to why such tendencies occur in their countries. Spanish data, on the other hand, imply that students or parents may be aware of the low priority given to spoken English in Spanish schools, where exams still tend to be only written, as noted in this respondent's comment "Unfortunately, the truth is that students must pass a written exam at the end of the year - there is no oral test. So I'm sorry to say oral skills are not the priority".

To conclude, these three aspects of life beyond school (subtitled television and films, opportunities to practice speaking, and private tuition) reflect a range of characteristics and realities in the countries we surveyed. A fuller picture of influences from outside the classroom is beyond the scope of this article and can only be obtained by further research into official and de facto influences, including national language policy, issues of language status, and regional and national imperatives.

\section{Conclusion}

The goal of this article was to examine quantitative and qualitative data from seven European countries in which teachers replied to an on-line teacher survey of English pronunciation teaching practices (EPTiES). The survey asked teachers to evaluate and comment on the training they had received to teach English pronunciation, what they do inside the classroom and what happens outside the classroom in terms of students' exposure to English.

Our questions about teacher training led several old myths to resurface, notably about how spending time in an English-speaking country equates with pronouncing English well and that having sound knowledge of phonetics and phonology is sufficient to be able to teach pronunciation. The results suggest that the respondents were generally satisfied with the training they had received, even though it did not involve much practice in teaching pronunciation. This was revealed in the comments to open-ended questions, where respondents often described their undergraduate training in phonetics and phonology, and/or the instruction they received to improve their pronunciation. Other comments made it clear that for some respondents, pronunciation is not necessarily seen as being a necessary part of communication skills. Overall, the teachers surveyed could be referred to as amateurs in terms of teaching pronunciation, as many of them are self-taught or have sought further training after starting teaching.

We investigated practices inside the classroom via a number of questions about materials, methods and assessment. One surprising finding was the limited use of established assessment scales, despite promotion of the CEFR throughout Europe. This could mean that the CEFR is not seen as relevant to the teaching or assessment of pronunciation. To a certain extent, this may also be true for phonetic symbols, as the respondents tended to teach learners to recognise symbols, rather than to write them. Generally, the respondents appeared satisfied with the amount of time they devoted to pronunciation teaching, as well as with the availability of technical help. Use of labs or portable sound players varied greatly between the seven countries, as did the use of dictionaries and textbooks. As might be expected, use of CDs and DVDs has overtaken older technologies.

In terms of assessing pronunciation, the respondents tended to prefer continuous assessment methods. Further research should probe why this approach is preferred and whether it is holistic or centred on different aspects of pronunciation such as segments, intonation, etc. Respondents indicated how and when they carry out pronunciation assessment by stating which tasks on a list they use and for which type of assessment. In all three categories (diagnostic, formative, evaluative), oral performance (e.g. presentations), reading aloud, listening followed by questions, and oral exams in pairs were much more popular than written tasks (e.g. transcription) and individual oral exams. This is not surprising because communication is the main purpose for which European secondary school pupils learn English; therefore, the most frequently used assessment tasks are the kinds that focus on communication skills. Further research could explore which aspects of oral performance are assessed, and which features are rewarded and/or penalised.

Three aspects of life beyond school (subtitled television programmes and films, opportunities to speak English, private tuition) were evaluated via teachers' appraisals of their students' habits (rather than the learners' own assessments of their habits). In terms of television programmes, Finland and Macedonia had the largest percentages of respondents who said their students had access to subtitled programmes on television and to subtitled films in cinemas. It was also in these two countries that the highest percentages of respondents felt their learners made use of these opportunities to expose themselves to English. In terms

\footnotetext{
${ }^{25}$ See also Bray (2011) for a discussion of private tutoring elsewhere in Europe.
} 
of films shown in the cinema, Finland and Poland had the highest percentages of respondents who indicated that their students make the greatest use of this source of exposure to English. In contrast, relatively few respondents in Germany and Spain felt their students had access to and made use of television and cinema resources. Switzerland had the highest percentage of respondents who said that learners take advantage of opportunities for face-to-face interaction in English, whereas recourse to on-line interactions was reported most frequently by respondents in Finland and Macedonia. Relatively few teachers in Finland, France and Switzerland stated that their learners received additional private tuition, in contrast to Macedonia, Poland and Spain, where more than half of our respondents felt that their learners probably call upon this oftenexpensive resource.

The EPTiES survey was designed to reveal possible differences between the countries surveyed. Not surprisingly, therefore, it generates more questions than answers. Although the quantitative and qualitative data it provides do not allow direct causal relationships to be established between factors, this paper suggests tentative explanations for some of these differences. Further research, including both classroom observation and learner surveys in order to verify some of the claims made by teachers, is now needed to assess these possible explanations.

Our results confirm that the CEFR remains an underused tool. Nevertheless, studies and reports reflecting the efforts of teachers and researchers to adapt the existing descriptors to take pronunciation into account more explicitly should soon start to appear. Teacher training, both pre- and in-service, is another sector that needs improving, for example, by clearly distinguishing between instruction in phonetics and phonology (knowing about English pronunciation) and training in pronunciation pedagogy (knowing how to teach pronunciation). Researchers and teachers are working quietly in all these areas and the results of their work are eagerly awaited.

\section{Acknowledgements}

EPTiES is a product of the authors' collaboration with Una Cunningham, Deirdre Murphy and Rias van den Doel. We would also like to thank all the teachers who responded to the survey.

\section{Bibliography}

Acton, William. 1984. "Changing Fossilized Pronunciation.” TESOL Quarterly 18: 71-85.

Berentzen, Katrin. 2009. "Learning through Soap Operas: Does Ordinary TV Assist Foreign-Language Competence?" Goethe Institut Web page : http://www.goethe.de/ges/spa/prj/sog/mud/en5023826.htm.

Bonnet, Gérard. 2002. "The Assessment of Pupils' Skills in English in Eight European countries: A European Project." Available at http://www.eva.dk/projekter/2002/evaluering-af-faget-engelsk-igrundskolen/projektprodukter/assessmentofenglish.pdf.

Bradford, Barbara and Joanne Kenworthy. 1991. "Phonology on Teacher Training Courses." Speak Out! 9: 12-15.

Bray, Mark. 2011."The Challenge of Shadow Education: Private Tutoring and its Implications for Policy Makers in the European Union. Brussels: European Commission. Available at http://www.nesse.fr/nesse/activities/reports/the-challenge-of-shadow-education-1.

Breitkreutz, Judith A., Derwing, Tracey M. and Marian J. Rossiter. 2001. "Pronunciation Teaching Practices in Canada." TESL Canada Journal 19/1: 51-61.

Burgess, John and Sheila. Spencer. 2000. "Phonology and Pronunciation in Integrated Language Teaching and Teacher Education." System 28/2: 191-215.

Council of Europe. 2001. Common European Framework of Reference for Languages: Learning, Teaching, Assessment. Cambridge: Cambridge University Press.

Couper, Graeme. 2011. "What Makes Pronunciation Teaching Work? Testing for the Effect of Two Variables: Socially Constructed Metalanguage and Critical Listening." Language Awareness 20/3: 159182.

Dimitrova, Snezhina and Tsvetanka Chernogorova. 2012. "English Pronunciation Models and TertiaryLevel Students: A Bulgarian Perspective.” In Exploring English Phonetics, edited by Tatjana Paunović and Biljana Čubrović, 208-224. Newcastle on Tyne: Cambridge Scholars Publishing.

Dörnyei, Zoltan and Tatsuya Taguchi. 2010. Questionnaires in Second Language Research: Construction, Administration, and Processing ( $2^{\text {nd }}$ ed.). New York: Routledge. 
European Commission. 2012. First European Survey on Language Competences. Available at $\mathrm{http} / / /$ ec.europa.eu/languages/policy/strategic-framework/documents/language-survey-finalreport_en.pdf

Foote, Jennifer A., Holtby, Amy K. and Tracey M. Derwing. 2011. "Survey of the Teaching of Pronunciation in Adult ESL Programs in Canada." TESL Canada Journal 29/1: 1-22.

Fraser, Helen. 2001. Teaching Pronunciation: A Handbook for Teachers and Trainers; Three Frameworks for an Integrated Approach. Sydney, Australia: New South Wales Department of Education and Training.

Gattegno, Caleb. 1972. Teaching Foreign Languages in Schools: The Silent Way (2 ${ }^{\text {nd }}$ ed.). New York: Education Solutions.

Gattegno, Caleb. 1976. The Common Sense of Teaching Foreign Languages. New York: Educational Solutions.

Gilbert, Judy. 2010. "Pronunciation as Orphan: What Can Be Done?" SpeakOut! 43: 3-7.

Henderson, A. (2013). "The English Pronunciation Teaching in Europe Survey (EPTiES): Initial results \& useful insights for collaborative work." In Waniek-Klimczak, E. and L. Shockey, (eds.), Teaching and researching English accents in native and non-native speakers, 123-140. Springer Verlag: Berlin Heidelberg.

Henderson, Alice, Frost, Dan, Tergujeff, Elina, Kautzsch, Alexander, Murphy, Deirdre, Kirkova-Naskova, Anastazija., Waniek-Klimczak, Ewa, Levey, David, Cunningham, Una. and Lesley Curnick. 2012. "The English Pronunciation Teaching in Europe Survey: Selected Results." Research in Language 10/1: 527.

Herry-Bénit, Nadine. 2011. Didactique de la Phonétique Anglaise. Rennes: Presses Universitaires de Rennes.

IFOP (Institut Français de l'Opinion Publique). 2010. "Les Français et le Téléchargement Illégal." Available at http://www.ifop.fr/?option=com_publication\&type=poll\&id=1227.

Kirkova-Naskova, Anastazija, Tergujeff, Elina, Frost, Dan, Henderson, Alice, Kautzsch, Alexander, Levey, David, Murphy, Deirdre, and Ewa Waniek-Klimczak. 2013. "Teachers' Views on their Professional Training and Assessment Practices: Selected Results from the English Pronunciation Teaching in Europe Survey." In Proceedings of the 4th Pronunciation in Second Language Learning and Teaching Conference, Aug. 2012, edited by John Levis and Kimberly LeVelle, 29-42. Ames, IA: Iowa State University.

Leppänen, Sirpa, Pitkänen-Huhta, Anne, Nikula, Tarja, Kytölä, Samu, Törmäkangas, Timo, Nissinen, Kari, Kääntä, Leila, Räisänen, Tiina, Laitinen, Mikko, Pahta, Päivi, Koskela, Heidi, Lähdesmäki, Salla and Henna Jousmäki. 2011. National Survey on the English Language in Finland: Uses, meanings and attitudes. Studies in Variation, Contacts and Change in English, Vol. 5. Available at http://www.helsinki.fi/varieng/journal/volumes/05.

Levey, David and Barbara Eizaga. Forthcoming. "Survey of Spanish University Students' English Language Habits." (Unpublished report). Universidad de Cadiz, Spain.

Lintunen, P. 2004. Pronunciation and Phonemic Transcription: A Study of Advanced Finnish Learners of English. Turku: University of Turku.

Macdonald, Shem. 2002. "Pronunciation: Views and Practices of Reluctant Teachers." Prospect: An Australian Journal of TESOL 17/3: 3-18.

Messum, Piers. 2012. "Teaching Pronunciation without Using Imitation : Why and How." In Proceedings of the 3rd Pronunciation in Second Language Learning and Teaching Conference, Sept. 2011, edited by John Levis and Kimberly LeVelle, 154-160. Ames, IA : Iowa State University.

Messum, Piers. 2007. "The Role of Imitation in Learning to Pronounce." PhD diss., University College London.

Murphy, Deirdre. 2011. An Investigation of English Pronunciation Teaching in Ireland." English Today 27/4: 10-18.

Murphy, John M. 1997. Phonology Courses Offered by MATESOL Programs in the U.S." TESOL Quarterly 31/4: 741-764.

Nowacka, Marta. 2010. "The Ultimate Attainment of English Pronunciation by Polish College Students: A Longitudinal Study." In Issues in Accents of English 2, edited by Ewa Waniek-Klimczak, 233-260. Newcastle upon Tyne: Cambridge Scholars Publishing.

Oller, Anne-Claudine and Dominique Glasman. 2013. "Forms and Stakes of Private Tutoring in France", In Private Tutoring Across the Mediterranean: Power Dynamics and Implications for Learning and 
Equity, edited by Bray, Mark, Mazawi, André E. and Ronald G. Sultana, 77-92. Rotterdam: Sense Publishers.

Paunović, Tatjana. 2009. "Plus ça Change... Serbian EFL Students' Attitudes towards Varieties of English." Poznań Studies in Contemporary Linguistics 45/4: 511-533. Available at http://versita.metapress.com/content/6563h54842u858nm/fulltext.pdf.

Sockett, Geoffrey. 2011. "From the Cultural Hegemony of English to Online Informal Learning: Cluster Frequency as an Indicator of Relevance in Authentic Documents." ASp, 60: 5-20.

Statistisches Bundesamt (www.desatis.de). 2003. "Bildung und Kultur. Berufliche Schulen" [Education and Culture. Vocational schools]. Fachserie 11, Reihe1. Wiesbaden. [http://www.destatis.de/jetspeed/portal/cms/Sites/destatis/Internet/DE/Content/Publikationen/Fachveroe ffentlichungen/BildungForschungKultur/Schulen/BeruflicheSchulen2110200047004,property=file.pdf.

Statistisches Bundesamt (www.desatis.de). 2011. "Bildung und Kultur. Berufliche Schulen" [Education and Culture. Vocational schools]. Fachserie 11, Reihe1. Wiesbaden. [http://www.destatis.de/jetspeed/portal/cms/Sites/destatis/Internet/DE/Content/Publikationen/Fachveroe ffentlichungen/BildungForschungKultur/Schulen/BeruflicheSchulen2110200117004,property=file.pdf.

Suomen elokuva Säätiö/SES [Finnish Film Foundation]. 2013. Elokuvavuosi 2012 [Facts \& Figures]. Helsinki: SES.

Tergujeff, Elina. 2013a. English Pronunciation Teaching in Finland. Jyväskylä : University of Jyväskylä. Available at http://urn.fi/URN:ISBN:978-951-39-5322-5.

Tergujeff, E. 2013b. "Learner Perspective on English Pronunciation Teaching in an EFL Context." Research in Language 11.1: 81-95.

Tergujeff, Elina. 2012. "English Pronunciation Teaching: Four Case Studies from Finland." Journal of Language Teaching and Research 3/4: 599-607.

Tergujeff, Elina, Ullakonoja, Riikka and Hannele Dufva. 2011. "Phonetics and Foreign

Language Teaching in Finland.” In XXVI Fonetiikan päivät 2010, edited by S. Werner and T. Kinnunen, 63-68. Joensuu, Finland: University of Eastern Finland.

Walker, Robin. 1999. "Proclaimed and Perceived Wants and Needs among Spanish Teachers of English." Speak Out! 24: 25-32.

Waniek-Klimczak, Ewa. 2002. "Context for Teaching English Phonetics and Phonology." In Accents and Speech in Teaching English Phonetics and Phonology, edited by Ewa Waniek-Klimczak and Patrick J. Melia, 139-152. Frankfurt am Main: Peter Lang.

Waniek-Klimczak, Ewa and Karol M. Klimczak. 2005. "Target in Speech Development: Learners' Views." In English Pronunciation Models: A Changing Scene, edited by Katrzyna Dziubalska-Kołaczyk and Joanna Przedlacka, 229-250. Bern: Peter Lang.

\section{Appendix: EPTiES Questions}

\section{Participant Information}

Please select your gender:

How old are you?

How many years have you been teaching English?

Is English your native language?

Where do you teach? (Select a country.)

Do you teach in the private sector?

(Finland) Please list your qualifications, for example LH, HK, ...

(France) Please list your qualifications, for example CAPES, Agrégation, BA, DipTEFL, MA TESOL, $\mathrm{PhD}$, IPA Certificate, etc.

(Macedonia, Poland, Spain, Switzerland) Please list your qualifications, for example BA, DipTEFL, MA TESOL, PhD, IPA Certificate, etc.

(Germany) Please list your qualifications, for example GrundschullehrerIn, HauptschullehrerIn,

RealschullehrerIn, GymnasiallehrerIn, Universitätsdozent, BA, DipTEFL, MA TESOL, PhD, IPA

(France)Please indicate the département in which you teach: 
(Germany) Please select the Bundesland in which you teach:

(Finland, France, Germany, Poland, Switzerland) Please select one of the following, about the type of area where you teach:

(Macedonia) Please indicate the town or postal code of the area where you teach:

(Switzerland) Please indicate the canton in which you teach:

(Spain) Please select one of the following, about the place where you teach:

(Poland) Please select one of the following, about the place where you teach:

(Finland, France, Germany) Please indicate at which level you teach:

Please state the native language(s) of your students.

Outside the Classroom

Are students exposed to English outside the classroom?

- Are TV programmes subtitled?

- Are foreign language films in the cinema subtitles?

- Are there opportunities for students to practice English outside the classroom?

- Do your learners receive private English language tuition outside the classroom?

- Do they watch news channels such as BBC World, CNN, etc.?

Estimate how often your learners are exposed to English outside the classroom via the following sources:

- Via subtitled TV programmes

- Via subtitled films at the cinema

- Via radio programmes

- Via phone interaction(s) with native and/or non-native speakers

- Via live interaction(s) with native and/or non-native speakers

- Via on-line resources such as e-mail, forums, chatroom, etc.

- Via other sources

\section{Pronunciation Teaching Methods}

Do you teach your learners how to RECOGNIZE phonetic symbols?

Why DO you or do you NOT teach your learners to recognize phonetic symbols?

Do you teach your learners to WRITE phonetic symbols?

Why DO you or do you NOT teach your learners to WRITE phonetic symbols?

Do you use ear training?

What percentage of your teaching time do you devote to teaching pronunciation PER WEEK?

What percentage of your teaching time would you LIKE to devote to teaching pronunciation PER

Do you feel this is a sufficient amount of time? Why or why not?

Teaching Materials

Do you use any of these published materials? You may select more than one. (Textbooks, Dictionaries,

CDs, Cassettes, Videos, DVDs).

Do you use any of these on-line materials? You may select more than one.

- Podcasts

- Pre-existing modules or courses

- Mailing lists

- Blogs

- Forums

- Social networking sites, eg. Facebook, ...

- Web sites intended for language learning, eg. VOA, BBC Learning English, ...

- Web sites not specifically intended for language learning

- "Virtual World" environment, eg. Second Life

Do you have access to a separate language lab? 
If yes, please indicate what type of language lab. You may select more than one. (cassette, digital, multimedia)

Do you have access to portable sound players?

If yes, please indicate what type of portable sound player. You may select more than one. (Tape player; Digital, eg. mp3 player, ...; CD player; Other).

How frequently do you use these resources: Separate language lab, Portable sound player.

Do you feel that you have sufficient access to technical help?

\section{Evaluation of Pronunciation}

Do you do an initial diagnostic for any of your learners?

Do you evaluate your learners' pronunciation at the end of a course and/or during the course?

Are any of your evaluations linked to an established scale, for example a national or international scale? If yes, please state which scale is used as a reference scale for your evaluations, eg. ACTEFL, CEF, etc.

Which types of tasks do you use for DIAGNOSTIC assessment of pronunciation skills? Please tick Which types of tasks do you use for FORMATIVE assessment of pronunciation skills? Please tick the ones you use.

Which types of tasks do you use for EVALUATIVE assessment of pronunciation skills? Please tick the ones you use.

- Written work, eg. transcription into symbols or letters, etc.

- Oral performances, eg. short sketches, dialogues, presentations, etc.

- Individual oral exams

- Oral exams in pairs

- Listening \& questions, eg. multiple-choice, short answer, note-taking, etc.

- Reading aloud (with or without preparation time)

- Other

- I don't know

- None of the above

\section{*(Finland)}

Do you do an initial diagnostic (lähtötaso) for any of your learners?

Which types of tasks do you use for DIAGNOSTIC (lähtötaso) assessment of pronunciation skills? Please tick the ones you use.

Which types of tasks do you use for FORMATIVE (väliarviointi) assessment of pronunciation skills?

Please tick the ones you use.

Which types of tasks do you use for EVALUATIVE (päättöarviointi) assessment of pronunciation skills? Please tick the ones you use.

\section{Teacher Training}

In relation to pronunciation, please rate the teacher training you received from 1 to 5 , with 1 as "extremely poor" and 5 as "excellent".

Please tell us how much training you received specific to teaching pronunciation. Feel free to mention any period of time (hours, months, years, etc.).

Please explain the content and/or style of the training you received. Feel free to mention types of courses, approaches, etc.

\section{Views/Attitudes}

For you personally, how important is English in relation to other languages? Please rate from 1 to 5, with 1 as "not important at all" and 5 "extremely important".

For you personally, how important is pronunciation in relation to other language skills? Please rate from 1 to 5 , with 1 as "the least important" and 5 as "the most important".

For you personally, how easy is it to teach English pronunciation? Please rate from 1 to 5, with 1 as "extremely difficult" and 5 as "extremely easy". 